\title{
Impact of Family Interference in Love Affairs: Critical Analysis of Jane Austen's Sense and Sensibility.
}

\author{
Alidou Razakou IBOURAHIMA BORO*
}

University of Parakou/R. Benin

*Corresponding Authors: Alidou Razakou IBOURAHIMA BORO, University of Parakou/R. Benin

\begin{abstract}
The aim of this research paper is to show and discuss the impact of family interference in love affairs through Sense and sensibility of Jane Austen. To reach the objectives of this paper, I've made a thorough, scrutiny and critical reading of Sense and Sensibility and with the new historicism theory, I've analyzed the social contest of England in the late eighteenth and early nineteenth centuries. Since this issue is not a point epoch and point area issue as it is always a current issue in modern societies throughout the world, I've made a pre and post analysis of the subject in question, how was the impact of family interference before Jane Austen's birth in Great Britain, how it was during her lifetime and how it is currently. The findings of this paper show that her work and the works of all pre-Romantic and Romantic writers has been so effective and their appeal has reached their audience that it rose another issues in the current British society. The backlash of their work has been out of control and it effects are bittersweet.
\end{abstract}

KEYWORDS: Impact, Interférence, Famille, affaire d'affaire, analyse critique.

RÉSUMÉ : Le but de cette étude est de montrer à travers une discussion, l'impact de l'interférence familiale dans les relations amoureuses à travers le roman Raison et Sentiments de Jane Austen. Pour atteindre mes objectifs, j'ai effectué une lecture complète, minutieuse et critique et grâce à la théorie de l'Historicisme, j'ai analysé le contexte social de l'Angleterre de la fin du dix-huitième et du début du dix-neuvième siècle. Vu que ce problème ne se réduit pas seulement à l'Angleterre du dix-huitième et dix-neuvième siècle, parce qu'il est toujours d'actualité dans certaines parties du monde, j'ai effectué une analyse du sujet dans l'Angleterre d'avant et d'après le dix-neuvième siècle. J'ai ainsi essayé de comprendre comment était l'impact de l'intervention familiale avant la naissance de Jane Austen en Grande-Bretagne, comment c'était pendant sa vie et comme c'est dans la société moderne actuelle. Les résultats de cette recherche montrent que les travaux de Jane Austen ainsi que ceux de tous les écrivains Préromantiques et Romantiques ont été concluantes efficaces et leur appel entendu qu'ils ont créés d'autres problèmes dans la société britannique actuelle. Les répercussions de leurs travaux ont été hors de contrôle qu'on pourrait qualifier leur victoire d'amère.

\section{INTRODUCTION}

Youth is marked by meetings, by love affairs and by engagement and promises of eternal love between lovers. The process is set to end with marriage as it is it consecration. Love affairs are mostly free, disinterested and of course secret. But when it comes to engagement and afterward marriage, it hardly could be done in secrecy, so it is exposed to the members of each lover's family for approval and by the same time, is exposed to their judgments, their appreciation and their influence. As engagement and marriages are the only way of forming and extending family, parents have naturally their word to say when it comes to accept someone in the family. Thence, lovers are confronted to the reality of life, and most of the time unfortunately for them, the fairytales they lived hitherto, often end in sorrow, with heartbreak and tears. The ancient time, the old society, is known to have been the worse period for lovers, where marriages are problems of deal rather than of heart or feelings. Reading Romantic Period authors such as Jane Austen in her Sense and Sensibility helps me to understand how important family interference could be in love affairs and what could be its consequences in lovers' lives. The problem here is that rare person try to understand why things were as they were in that period, why did family interfere and stole the happiness of their children that they swap with their security? Why did they prefer marriages of sense rather than marriages of sensibility? My motive is to show the impact and discuss family's interference in love affairs in Sense and Sensibility of Jane Austen. For the purpose of this paper, I went through the reading of novels from different generations and different settings, going from the Sixteenth to the Twenty first century, from 
Europe to Africa. I also made a documentation and a large research to understand the impact of family interference in love affairs. In order to better understand the impact of family interference in love affairs, I went through New Historicism theory. This theory is a fictional theory which objective is to understand intellectual past through literature, and literature through its cultural context. It seems necessary to me to understand the context in which the novel has been written before putting any judgment on its content.

\section{RESULTS}

Family has always been the cement of all societies throughout ages. Family welcomes you at the birth, back you at every stormy moment of your life and burry you at the end of your existence. From the dawn to the twilight, family is always there. For every parents, even monsters, the well-being of their children has always been their main purpose. They try to secure them a good marriage, a bright future and put them out of need and for this reason they think with their head instead of their heart when it comes to approve a union. They have been married on the same principle and try to secure the same kind of marriage for their children and it could easily be understood we glanced at the society in which they belong.

\subsection{Family Interference In Love Affairs In Literature}

As novelists primarily role is to deal with the problems of their time, I could lay on the writings of pre-Austen authors to understand the impact of family interference in love affairs in the old British society. Authors like Williams Shakespeare and Daniel Defoe could be picked among several other for the purpose of this study. The most dramatic novel about this topic is the famous Romeo and Juliet. In his play, Shakespeare shows how dangerous family interference could be in love affairs. In fact, young Romeo and Juliet have been forbidden to love each other because of their families' cold relationship. Capulets and Montagues strongly opposed themselves against any union between their children because of a long term resentment between them. And the impact was dramatic, resulting to the death of their children. Two centuries after, Daniel Defoe through his Moll Flanders highlighted the same problem, showing that family interference becomes somehow an obstacle to pass. In Moll Flanders, the character of Robin wishing to marry Mrs. Betty seek for the whole family approval. He firstly confronts his mother:

'By my faith, madam,' says Robin, "tis in vain to mince the matter or tell any more lies about it; I am in earnest, as much as a man is that's going to be hanged. If Mrs. Betty would say she loved me, and that she would marry me, I'd have her tomorrow morning fasting, and say, 'To have and to hold,' instead of eating my breakfast.' 'Well,' says the mother, 'then there's one son lost'; and she said it in a very mournful tone, as one greatly concerned at it. (Defoe 67).

Furthermore, on page 68, Robin's sisters invite themselves in the conversation he is having with his mother to let their opinions known about the matter.

'Why, but, child,' says the old lady, 'she is a beggar.' 'Why, then, madam, she has the more need of charity,' says Robin; 'I'll take her off the hands of the parish, and she and I'll beg together.' 'It's bad jesting with such things,' says the mother. 'I don't jest, madam,' says Robin. 'We'll come and beg your pardon, madam; and your blessing, madam, and my father's.' 'This is all out of the way, son,' says the mother. 'If you are in earnest you are undone.' [...] after all my sister's huffing and blustering, I believe I shall never be able to persuade her to it.' [...] 'No, Mrs. Mirth-wit,' says Robin, 'Mrs. Betty's no fool; but Mrs. Betty may be engaged some other way, and what then?' 'Nay,' says the eldest sister, 'we can say nothing to that. Who must it be to, then? She is never out of the doors; it must be between you.' 'I have nothing to say to that,' says Robin. 'I have been examined enough; there's my brother. If it must be between us, go to work with him.' [...] 'Prithee,' says he, 'don't go to shame your stories off upon me [...] 'No,' says the eldest sister, 'I dare answer for my brother; he knows the world better.' (Defoe 68-69).

A second conversation of that kind occurs, involving Robert, her mother and sisters. 
'Sit down, Robin,' says the old lady, 'I must have some talk with you.' [...] 'I hope it is about a good wife, for I am at a great loss in that affair.' 'How can that be?' says his mother; 'did not you say you resolved to have Mrs. Betty?' 'Ay, madam,' says Robin, 'but there is one has forbid the banns.' 'Forbid, the banns!' says his mother; 'who can that be?' 'Even Mrs. Betty herself,' says Robin. 'How so?' says his mother. 'Have you asked her the question, then?' 'Yes, indeed, madam,' says Robin. 'I have attacked her in form five times since she was sick, and am beaten off; the jade is so stout she won't capitulate nor yield upon any terms, except such as I cannot effectually grant.' 'Explain yourself,' says the mother, 'for I am surprised; I do not understand you. I hope you are not in earnest.'[...] Here the sisters put in. 'Madam,' says the second sister, "tis impossible to be serious with him; he will never give a direct answer to anything [...] (Defoe 77-78).

Defoe through his character Robert hints that it is greatly necessary to have the approval of the family in the pre-Austen England, especially the father and mother. The following conversation is a good illustration.

'how can I resolve that point, when you see I cannot have her without your consent? Besides, I am not bound to marry at all. But this I will say, I am in earnest in, that I will never have anybody else if I can help it; so you may determine for me. Betty or nobody is the word, and the question which of the two shall be in your breast to decide, madam, provided only, that my goodhumoured sisters here may have no vote in it.' (Defoe 79-80).

Writers are the painters of their epoch, I can assume that Shakespeare and Defoe painted the preAusten England. Through their writings I could easily remarked that family has to approve any union. Its hence has the right to accept or reprove a union. For the impact of this interference, it could be dramatic as the death of Romeo and Juliet or without impact if lovers decide to take it easy and accept the proposal of their parents.

\subsection{Family Interference in Love Affairs in Jane Austen' Sense And Sensitivity}

Several authors such as Daniel Defoe, William Shakespeare and even John Locke denounced family interference and recommended fundamental changing in the nature of marriage relationship, the British society in general hasn't changed at all. Due to the industrial revolution that occurred in the British society, families in the late eighteenth- century England mostly operated as economic units and marriage provided ways of securing property and fortune. It was especially important for parents to secure right spouse for their children. All this to mean that family interference is still part of the customs, and seems to be necessary for the wellbeing of the whole family.

In her novel Sense and Sensibility, Jane Austen dealt as she used to in her works, with the debate over parental wishes versus personal choice and over money and social status versus marriage. In her novel, Lucy Steel who was secretly engaged with Edward Ferrars, declared this to Elinor: "In a moment I shall see the person that all my happiness depends on that is to be my mother!" (Austen $\mathrm{p}$ 343) When family discovered all about their relationship, the family of Edward, especially her mother went red. The mother strongly reproved the relation, threated to take severe measures towards Edward.

His mother explained to him her liberal designs, in case of his marrying Miss
Morton; told him she would settle on him the Norfolk estate, which, clear of
land-tax, brings in a good thousand a-year; offered even, when matters grew
desperate, to make it twelve hundred; and in opposition to this, if he still
persisted in this low connection, represented to him the certain penury that
must attend the match. His own two thousand pounds she protested should be
his all; she would never see him again; and so far would she be from
affording him the smallest assistance, that if he were to enter into any
profession with a view of better support, she would do all in her power to
prevent him advancing in it.' (Austen pp 391-392).

Rather than Lucy she would have preferred Miss Morton, and she discussed about the matter with the elder sister of Edward, without mentioning it to him before. 
for she had just been saying to your brother, only five minutes before, that she thought to make a match between Edward and some Lord's daughter or other, Iforget who". (Austen $p$ 379)

As Edward disappointed the family, the Ferrars decided to swap Edward with is younger brother Robert to marry Miss Morton.

We think NOW,' [...] 'of ROBERT'S marrying Miss Morton.' Elinor[...] calmly replied, 'The lady, I suppose, has no choice in the affair.' 'Choice! how do you mean?' 'I only mean that I suppose, from your manner of speaking, it must be the same to Miss Morton whether she marry Edward or Robert.' 'Certainly, there can be no difference; for Robert will now to all intents and purposes be considered as the eldest son; and as to anything else, they are both very agreeable young men: I do not know that one is superior to the other.' (Austen pp 437-438).

Robert once talked about his feelings regarding the misfortunes of his brother, and wished he had behaved otherwise.

I offered immediately, as soon as my mother related the affair to me, to talk to him myself, and dissuade him from the match;" ( $p$ 442) "I should have said, 'consider what you are doing. You are making a most disgraceful connection, and such a one as your family are unanimous in disapproving. (Austen p 442).

After the storm that hit the Ferrars family, Edward come back to the pardon of his mother and talk about his marrying Elinor. Here again, her mother has had her word to say, even if, she was somehow forced to accept the deal.

she judged it wisest, from the experience of the past, to submit-and therefore, after such an ungracious delay as she owed to her own dignity, and as served to prevent every suspicion of good-will, she issued her decree of consent to the marriage of Edward and Elinor." (Austen p 557).

These passages prove that family interference was still part of the late eighteenth century in England. Through the reading of Sense and Sensibility, I can easily remark how important was family in someone's life during the eighteenth century. In one way or another, family interferes in love affairs, whether to back and arrange little secret meetings, advice for perseverance and organize balls and gatherings to help young people meeting together. The characters of John Middleton and his mother in law Mrs. Jennings are the perfect example of teasers. They spent long hours inquiring, to find out who loves who and employed much of the remaining hours of the day on teasing young ladies about their lovers.

\subsection{Jean Austen's Perception of Love Interference}

A close, careful and thorough reading could allow any reader to understand the position of Jane Austen in family interference in love affairs. She uses her characters Mrs. Jennings, Colonel Brandon, and Mrs. Dashwood to express her will. Her compassion for the characters of Edward and Colonel Brandon and her depiction of Mrs. Ferrars prove that she is against any interference in love affairs. On the page 20 of the novel Mrs Dashwood uttered that it was contrary to every doctrine of her's that difference of fortune should keep any couple asunder who were attracted by resemblance of disposition. Further in the novel, when Mrs. Ferrars tried unsuccessfully to interfere in Edward's love affairs and dismissed him, Mrs. Jennings expressed her conviction, wondering what reason could impeach the marriage of two lovers.

I have no pity for either of them. I have no notion of people's making such a to-do about money and greatness. There is no reason on earth why Mr. Edward and Lucy should not marry. (Austen p 381).

She then, expressed her strong support to the behavior of Edward, pitying his situation:

Poor young man! - and what is to become of him?' (Austen p 394)

'Poor young man!' cried Mrs. Jennings, (Austen p 395). 
She furthermore proposed her assistance to this poor soul as she described Edward. "I am sure he should be very welcome to bed and board at my house; and so I would tell him if I could see him." (Austen p 395). Jane Austen also used the character of Colonel Brandon to show her disdain of family interference in love affairs.

The cruelty, the impolitic cruelty, '-[...] - 'of dividing, or attempting to divide, two young people long attached to each other, is terrible.Mrs. Ferrars does not know what she may be doing - what she may drive her son to. [...]" (Austen p 416).

He also, after Mrs. Jennings proposed to harbor the poor Edward at one of hid properties.

Will you be so good as to tell him that the living of Delaford, now just vacant, as I am informed by this day's post, is his, if he thinks it worth his acceptance" (Austen $p$ 416).

\title{
2.4. Critical Analysis of the Impacts of Family Interference in Love Affairs in Jane Austen's Sense and Sensibility
}

When family decide to interfere, it could lead to several backlash on the couple or even on the entire family. It could be more or less dramatic but also beneficial sometimes for one or for both parties of the couple. It could end to breaks or even to union depending on how the interference was and how it occurred. In Sense and Sensibility of Jane Austen, the first impact of family interference in love affairs is the failure of the marriage of Colonel Brandon's brother with Eliza, a girl that the colonel loved and affectionate with all his heart. After her marrying his brother against her inclination, the brother who didn't love her at all always treat her unkindly, and the consequence was naturally a painful divorce. She became miserable and hardly could the colonel recognize her when he finally found her after a long inquiry.

\begin{abstract}
So altered —so faded - worn down by acute suffering of every kind! Hardly could I believe the melancholy and sickly figure before me, to be the remains of the lovely, blooming, healthful girl, on whom I had once doted. [...] Life could 14 do nothing for her, beyond giving time for a better preparation for death; and that was given. [...] I visited her every day during the rest of her short life: I was with her in her last moments.' (Austen p 306).
\end{abstract}

The most poignant example of the novel is the situation of Mrs. Ferrars, the mother of Edward and Roberts. She harshly reproved the connection of her elder son with any other girl but Mrs. Morton who were her choice for him. The result of this interference was a brutal family separation. Edward choose to ignore her recommendation due to his honor and was then dismissed by her mother. His primogenital right was removed from him for Robert. He was condemned to poverty and with no hope of any assistance of any kind. Edward lost, Mrs. Ferrars try to swap him with her remaining son to marry Mrs Morton, and once again, it appeared that she, once again made a wrong move. Robert, against her will married the same Lucy Steel. He too, was dismissed immediately. At the end, she lost both sons due to her wish to interfere. The consequence is then the fraction of the family. Everybody suffered of that situation.

\begin{abstract}
Mrs. Ferrars was the most unfortunate of women-poor Fanny had suffered agonies of sensibility (Austen $p$ 552)

'Mrs. Ferrars has never yet mentioned Edward's name, [...] Perhaps, however, he is kept silent by his fear of offending, and I hint, by a line to Oxford, that his sister and I both think a letter of proper submission from him, addressed perhaps to Fanny, and by her shewn to her mother, might not be taken amiss; for we all know the tenderness of Mrs. Ferrars's heart, and that she wishes for nothing so much as to be on good terms with her children.' (Austen p 553).
\end{abstract}

It has also led to an argument between John Dashwood and Mrs. Jennings when talking about the matter, the first blaming Edward and Lucy and the second defending them.

Then,' cried Mrs. Jennings with blunt sincerity, no longer able to be silent, 'he has acted like an honest man! I beg your pardon, Mr. Dashwood, but if he 
had done otherwise, I should have thought him a rascal. I have some little concern in the business, as well as yourself, for Lucy Steele is my cousin [...] John 15 Dashwood was greatly astonished; but his nature was calm, not open to provocation, and he never wished to offend anybody, especially anybody of good fortune. He therefore replied, without any resentment [...]'I would by no means speak disrespectfully of any relation of yours, madam. […]. (Austen p 393).

Like in Eighteenth century' Europe, family interference was also part of the nineteenth and twentieth centuries' Africa. The most striking novel dealing with the matter is Sous l'Orage by SeydouBadian. Every smart reader of Sous l'Orage will understand that Badian, like pre-Romantic and Romantic Period British writers, was against interference in love affairs, but he took the subject with another approach. He wrote in Sous l'Orage "l'homme n'est rien sans l'homme, il vient dans leur main et s'en va dans leur main" (Badian, 1972). It could be explained as human beings are nothing without their fellows, they come in their hands and leave in their hands. He wroteafterwardle mariage n'est pas une plaisanterie, il ne peut être réglé par ceux qui ne rêvent que de cinéma, de cigarettes et de bals (Badian, 1972). That can be translated as “marriage is not a joke, it can't be settled by dreamers of operas, cigarettes and balls. By these statements, he, like Molière shows the importance of the matter that is marriage but also hints that it should be settled by the whole family gathered for the purpose. Marianne and the young Eliza has learnt it at their own expense. Willoughby has deceived both and the pain occasioned was so hard and deep to the two ladies. Eliza has been abandoned by Willoughby who pretended to love her and who impregnated her.

Austen stated in her novel "He had left the girl whose youth and innocence he had seduced, in a situation of the utmost distress, with no creditable home, no help, no friends, ignorant of his address! He had left her, promising to return; he neither returned, nor wrote, nor relieved her."' (Austen p309).

The case of the beautiful Marianne is more painful. She loved him earnestly with all her heart and she even convinced herself of their marrying together, and always acted as they were engaged. She leaved her beloved mother in their cottage only to join him at London. But she was also deceived and the disappointment occasioned has almost drag her to her grave.

I saw that my own feelings had prepared my sufferings, and that my want of fortitude under them had almost led me to the grave. My illness, I well knew, had been entirely brought on by myself by such negligence of my own health, as I had felt even at the time to be wrong. Had I died, - it would have been self-destruction. (Austen p 513).

It was only when the deception occurred that they realized the kind of man Willoughby were.

The whole of his behaviour,' replied Elinor, 'from the beginning to the end of the affair, has been grounded on selfishness. [...] His own enjoyment, or his own ease, was, in every particular, his ruling principle.' 'It is very true. MY happiness never was his object.' 'At present,' continued Elinor, 'he regrets what he has done. And why does he regret it? - [...] But does it follow that had he married you, he would have been happy? - [...] probably would soon have learned to rank the innumerable comforts of a clear estate and good income as of far more importance, even to domestic happiness, than the mere temper of a wife.' (Austen p 521).

Considering the pitiful situation on which Eliza has been left and the situation on which Willoughby's deception led Marianne, both would have been grateful, had someone forbade their love affairs or at least inquired on the villain Willoughby. Eliza would have not ended as her mother and the beautiful Marianne would have blessed all the saints if her sister and her mother had interfered in her affairs with Willoughby. The characters of Marianne and her mother Mrs Dashwood have even recognized that they made some mistakes on the affair: the mother for being too passive and Marianne for being too credulous concerning Willoughby's feelings towards herself. 
I have not a doubt of it,' said Marianne; 'and I have nothing to regretnothing but my own folly. 'Rather say your mother's imprudence, my child,' said Mrs. Dashwood; 'SHE must be answerable.' Marianne would not let her proceed; - and Elinor, satisfied that each felt their own error, wished to avoid any survey of the past that might weaken her sister's spirits;' (Austen $p$ 522).

Poor choices due to youth could also been a real motive for family interference. Edward found himself trapped in an engagement with his fiancée Lucy and despite his love for Elinor, he was somehow compelled to pursue the affair with Lucy, on the sake of his honor, and of course on the sake of his stupidity. Had he consulted someone, such a decision would never have been advised to the young man that he was when taking the engagement with Lucy.

\section{CONCLUSION}

Family interference in love affairs has been different throughout the ages and throughout the world. Europeans societies due to their drastic social changing in the eighteenth and nineteenth centuries, have turned marriage to financial affairs, with no regard to the feelings of the spouses. As long as money could be secure for one party of both, the marriage should be acted. This dreadful situation has led to many issues and this problematic situation has caught the attention of many theorists and authors who dedicated their pen to its resolution. As for the result, we could remark that they did very well, and one could even think that they did so well that the backlashes of their work has been out of control, turning from sweet to bitter with years. Indeed, one would bitterly remark that the effectiveness of her work and those of all the pre-Romantic and Romantic writers and the fact that their appeal reached their audience has raised today other issues in British society. It is important to remark that since the nineteenth century, Europeans societies have been turned to individualist societies. Austen's works have participated to the rising of this individualist society that characterized today the western societies and this deep desire to solve everything alone, out casting by the way the family and devaluating its original role that is to protect and assist every member in every situation that they can face in their life time.

As interference was also a reality in African societies, SeydouBadian also wrote about the theme and gave his point of view, which every smart reader would understand: he was against family "hard" interference in love affairs. He too, as English writers in the eighteenth and nineteenth century, recognized that love affairs should be free of family interference, and denounced the kind of commercialization of girls in Africa, but with a wisest approach. He, unlike English Pre-Romantic and Romantic Period insisted on the fact that family should not be ignored, but respected and that ancient should not be taken as enemies and at the same time encouraged ancient to take the feelings and opinions of young people into account before taking important decisions regarding their lives. The major difference lays there, Romantics went in war against interference and de facto against family, while Badian went in mediation and the backlashes of their combat show two different realities on the field today. Indeed, it is a fact that interference is still part of the current African societies, and it is a fact that it could be often hard for lovers, but it has lessened, and the commercialization Badian has denounced through his novel almost disappeared. In the other hand, it is also a fact that interference disappeared from the British societies, but only to create a far more serious concern. Indeed, no society in the world has a greater divorce rate that the British society and to hint that there is no link between the combat of the Romantic Movement and the current situation is only make proof of ignorance. Of course everybody may have his own preference but from two evils, chose the lesser, if interference could help to have better and enduring marriage, isn't better to have family together than having single parent raising alone children or raising them in two different houses? Could she make a time travel and witness the problem of the current British society, Austen would have perhaps switched her move and reconsidered the situation.

\section{REFERENCES}

[1] Austen Jane, Sense and Sensibility, Military Library: Whitehall, London Western Literature and Culture Supervisor: Paul Franssen July 2008.

[2] Badian Seydou, Sous l'Orage Ed Présence Africaine 1972 
Impact of Family Interference in Love Affairs: Critical Analysis of Jane Austen's Sense and Sensibility.

[3] Jane Austen: Parents and Parenting by Sarah de Vink 0220833 MA Thesis

[4] Molière, l'Avare, 1668

Citation: Alidou Razakou IBOURAHIMA BORO. "Impact of Family Interference in Love Affairs: Critical Analysis of Jane Austen's Sense and Sensibility.” International Journal on Studies in English Language and Literature (IJSELL), vol 8, no. 11, 2020, pp. 41-48. doi: https://doi.org/10.20431/2347-3134.0811005.

Copyright: (C) 2020 Authors. This is an open-access article distributed under the terms of the Creative Commons Attribution License, which permits unrestricted use, distribution, and reproduction in any medium, provided the original author and source are credited. 